Article history: Submitted 4 December 2020; Accepted 18 January 2021; Available online 1 February 2021.

\title{
Kebijakan Restrukturisasi Pinjaman Pada Peer To Peer Lending
}

\author{
Salsabila Yuharnita \\ salsabila.yuharnita-2017@fh.unair.ac.id \\ Universitas Airlangga
}

\begin{abstract}
Keywords:
Covid-19;

Abstract

Loans Services,

COVID-19 outbreak are global pandemic that affect every country especially Indonesia.

The impact of COVID-19 effects on society, human population, global environment and Restructurisation. economic. One of the economy impact after corona viruses can we found it on Peer to Peer Lending (P2PL). P2PL have since accessed by online transactions because P2PL represents a method of borrowing and lending online through a digital marketplace. Due the COVID-19 has serious effect, there is the risk of the borrower, it can be the loans taken out. The P2PL Lending operators plays the role to provide or offer restructurisation for borrowers but facility related provisions of restructurisation depends on the administrator since there are no regulations governing the loan restructuring for P2PL. There is several loan restructuring efforts can be made in P2PL, it called grace period. If a loan restructuring has been carried out, but there is still a dispute, it can be resolved by litigation or non-litigation channels.
\end{abstract}

\section{Kata Kunci: \\ Covid-19; \\ Layanan Pinjam Meminjam; \\ Restrukturisasi.}

\begin{abstract}
Abstrak
Covid-19 merupakan sebuah pandemi yang dialami oleh banyak negara di dunia, termasuk Indonesia. Adanya pandemi ini berdampak pada berbagai sektor, salah satunya ekonomi. Dampak ekonomi salah satunya dirasakan dalam perjanjian pinjam-meminjam yang saat ini marak digunakan yaitu perjanjian pinjam meminjam uang berbasis teknologi atau Peer to Peer Lending (P2PL). P2PL tidak dilakukan secara tatap muka, tetapi hanya melalui online. Penyelenggara P2PL merupakan perantara antara pemberi pinjaman dan penerima pinjaman. Dalam kondisi pandemi, P2PL mengalami kemungkinan risiko yaitu gagal bayar oleh penerima pinjaman. Untuk mengurangi risiko gagal bayar, penyelenggara P2PL menawarkan fasilitas pengajuan restrukturisasi pinjaman bagi penerima pinjaman. Ketentuan terkait fasilitas restrukturisasi pinjaman ditentukan oleh masing-masing penyelenggara karena belum adanya peraturan yang mengatur terkait restrukturisasi pinjaman pada P2PL. Beberapa upaya restrukturisasi pinjaman yang dapat dilakukan dalam P2PL yaitu grace period dan perpanjangan waktu. Apabila telah dilakukan upaya restrukturisasi pinjaman, namun tetap terjadi sengketa, maka dapat diselesaikan dengan jalur litigasi maupun nonlitigasi.
\end{abstract}

\section{Pendahuluan}

Corona Virus Disease2019atau yang selanjutnya disebutCOVID-19 merupakan penyakit menular yang disebabkan oleh coronavirus yang menyebabkan penyakit pada hewan dan manusia. Sejak akhir tahun 2019 COVID-19 menyebar secara cepat dan meluas sehingga lebih dari 200 negara di dunia terkena COVID-19, salah 
Salsabila Yuharnita: Kebijakan Restrukturisasi Pinjaman...

satunya Indonesia. Dengan meningkatnya jumlah korban dan kerugian harta benda, juga meluasnya wilayah yang terpapar, serta menimbulkan implikasi pada aspek sosial ekonomi yang luas di Indonesia, dikeluarkan Keputusan Presiden RI Nomor 12 Tahun 2020 tentang Penetapan Bencana Nonalam Penyebaran Corona Virus Disease 2019 yang selanjutnya disebut COVID-19 sebagai Bencana Nasional.

Setelah ditetapkan sebagai bencana nasional, pemerintah melakukan upaya-upaya guna mengurangi penyebaran Covid-19 dengan mengeluarkan berbagai kebijakan. Dampak yang dialami masyarakat menjadi lebih kompleks dengan adanya kebijakan-kebijakan tersebut, masyarakat semakin terbatas dalam melakukan kegiatannya. Sektor-sektor yang terkena dampak meliputi sektor politik, ekonomi, pariwisata, dan lain-lain. Dari berbagai sektor yang dialami, ekonomi merupakan sektor yang mengalami dampak yang cukup besar. Kegiatan ekonomi yang marak dilakukan oleh masyarakat adalah pengajuan kredit. Pemberian Kredit tidak hanya dilakukan pada sektor perbankan tetapi juga pada lembaga pembiayaan dan juga yang saat ini banyak diminati masyarakat yaitu pinjam meminjam berbasis online.

Pinjam meminjam berbasis online dilakukan financial technology yang mempermudah masyarakat mengakses produk-produk keuangan. Salah satu produk yang dihasilkan adalah layanan pinjam meminjam uang berbasis teknologi informasi atau disebut Peer to Peer Lending. Peer to Peer Lending memberikan inovasi dalam pinjam meminjam dikarenakan tidak perlu bertemu secara langsung tetapi melalui aplikasi atau laman website. Dampak pada kredit atau pembiayaan saat pandemi Covid-19 terjadi karena masyarakat mengalami kesulitan untuk memenuhi prestasinya. Terdapat beberapa kemungkinan yang terjadi seperti terlambat memenuhi prestasi dan risiko gagal bayar oleh peminjam.

Untuk mengatasi kemungkinan risiko gagal bayar pada kredit atau pembiayaan maka dikeluarkan peraturan untuk memberikan skema baru untuk penyelesaian kredit pada lembaga bank dan lembaga non-bank. Namun, belum ada peraturan yang mengatur terkait pinjaman pada Peer to Peer Lending. Oleh karena itu, restrukturisasi pinjaman pada Peer to Peer Lending saat ini dilakukan oleh tiap- 
tiap penyelenggara dengan ketentuan yang berbeda. Adanya kebijakan ini tidak serta merta memberikan keringanan kepada peminjam karena penyelenggara harus menganalisa, menyeleksi, dan merekomendasikan peminjam yang berhak mendapat restrukturisasi pinjaman. ${ }^{1}$

\section{Metode Penelitian}

Tipe penelitian yang digunakan adalah doctrinal research. Penelitian doctrinal research adalah penelitian yang menelaah dan menganalisis Peraturan Perundang-Undangan dan literatur yang berkaitan dengan isu hukum yang dikaji. Penelitian ini akan menjelaskan secara sistematis terkait isu hukum dengan aturan. Pendekatan yang digunakan dalam penulisan ini yaitu pendekatan Statute Approach dan Conceptual Approach.

\section{Karakteristik Perjanjian dalam Peer to Peer Lending}

Peer to Peer Lending yaitu Peraturan Otoritas Jasa Keuangan Nomor 77/ POJK.01/2016 tentang Layanan Pinjam Meminjam Uang Berbasis Teknologi Informasi dan Surat Edaran OJK Nomor 18/SEOJK.02/2017 tentang Tata Kelola dan Manajemen Risiko Teknologi Informasi Pada Layanan Pinjam Meminjam Uang Berbasis Teknologi Informasi. Peraturan ini dibuat agar tidak terjadi kekosongan hukum dan menjamin kepastian hukum bagi para pengguna layanan Peer to Peer Lending.

Definisi Peer to Peer Lending tercantum dalam Pasal 1 angka 3 Peraturan Otoritas Jasa Keuangan Nomor 77/POJK.01/2016 tentang Layanan Pinjam Meminjam Uang Berbasis Teknologi Informasi, yaitu:

Layanan Pinjam Meminjam Uang Berbasis Teknologi Informasi adalah penyelenggaraan layanan jasa keuangan untuk mempertemukan pemberi pinjaman dengan penerima pinjaman dalam rangka melakukan perjanjian pinjam meminjam dalam mata uang rupiah secara langsung melalui sistem elektronik dengan menggunakan jaringan internet.

1 R Quiserto, 'Cara Restrukturisasi Pinjol Pinjaman Online Fintech P2P Covid-19 2020' (Duwitmu, 2020). 
Peer to Peer Lending berbeda dengan perbankan dan juga lembaga pembiayaan. Dalam Peer to Peer Lending sebagian besar tidak diperlukan agunan sehingga layanan keuangan yang dilakukan lebih cepat, selain itu prosesnya lebih mudah dengan memanfaatkan gawai. ${ }^{2}$ Selain itu, terdapat perbedaan lainnya yaitu perjanjian Peer to Peer Lending dituangkan dalam Dokumen Elektronik. Berdasarkan data OJK pada November 2020, di Indonesia sudah ada 153 perusahaan Financial Technology yang terdaftar. ${ }^{3}$ Perjanjian yang dilakukan dalam Peer to Peer Lending dilakukan antara subyek hukum meliputi orang perorangan ataupun badan hukum secara online. Dalam praktiknya, perjanjian Peer to Peer Lending melibatkan 3 (tiga) pihak, yaitu:

a. Pemberi pinjaman sebagaimana diatur dalam Pasal 1 angka 8 Peraturan Otoritas Jasa Keuangan Nomor 77/POJK.01/2016 tentang Layanan Pinjam Meminjam Uang Berbasis Teknologi Informasi merupakan orang, badan hukum, dan/atau badan usaha yang mempunyai piutang karena perjanjian Peer to Peer Lending;

b. Penerima pinjaman diatur dalam Pasal 1 angka 7 Peraturan Otoritas Jasa Keuangan Nomor 77/POJK.01/2016 tentang Layanan Pinjam Meminjam Uang Berbasis Teknologi Informasi yaitu orang dan/atau badan hukum yang mempunyai utang karena perjanjian Peer to Peer Lending;

c. Penyelenggara layanan yang merupakan badan hukum Indonesia yang menyediakan, mengelola, dan mengoperasikan layanan Peer to Peer Lending, sesuai dengan Pasal 1 angka 6 Peraturan Otoritas Jasa Keuangan Nomor 77/ POJK.01/2016 tentang Layanan Pinjam Meminjam Uang Berbasis Teknologi Informasi.

Perjanjian dilakukan antara pemberi pinjaman dan penerima pinjaman, sedangkan penyelenggara merupakan pihak ketiga yang menyediakan tempat atau platform marketplace. Adanya beberapa pihak dalam penyelenggaraan

2 Trisadini Prasastinah Usanti et al, 'The Legal Principle of Collateral in Fintech Lending' (2019) 3 Hang Tuah Law Journal <http://law-journal.hangtuah.ac.id/index.php/htlj/article/ view/137>.

3 Otoritas Jasa Keuangan, 'Perusahaan Fintech Lending Berizin Dan Terdaftar Di OJK' (Otoritas Jasa Keuangan, 2020). 
Peer to Peer Lending menghasilkan hubungan hukum antar pihak yaitu pemberi pinjaman, penerima pinjaman, dan penyelenggara layanan pinjam meminjam uang berbasis teknologi informasi. Hubungan hukum lahir dari perikatan yang berasal dari perjanjian, untuk itu hubungan hukum dapat dilihat dari Pasal 18 Peraturan Otoritas Jasa Keuangan Nomor 77/POJK.01/2016 tentang Layanan Pinjam Meminjam Uang Berbasis Teknologi Informasi. Terdapat 2 jenis perjanjian pelaksanaan Layanan Pinjam Meminjam Uang Berbasis Teknologi Informasi, meliputi:

a. Perjanjian antara Penyelenggara dengan Pemberi Pinjaman; dan

b. Perjanjian antara Pemberi Pinjaman dan Penerima Pinjaman.

\section{Makna Gagal Bayar Penerima Pinjaman Pada Peer to Peer Lending}

WanprestasidiaturdalamPasal1238BWyang menjelaskandebitordinyatakan lalai dengan surat perintah, atau dengan akta sejenis itu, atau berdasarkan kekuatan dari perikatan sendiri, yaitu bila perikatan ini mengakibatkan debitor harus dianggap lali dengan lewatnya waktu yang ditentukan. Wanprestasi dalam penyelenggaraan Peer to Peer Lending sama halnya dengan wanprestasi pada umumnya. Apabila debitor melakukan wanprestasi dapat dituntut oleh kreditor untuk melakukan beberapa hal, yaitu: a. Pemenuhan perjanjian; b. Pemenuhan perjanjian dengan disertai ganti rugi; c. Ganti rugi; d. Pembatalan perjanjian; e. Pembatalan perjanjian disertai ganti rugi.

Dalam penyelenggaraan Peer to Peer Lending dimungkinkan terjadi gagal bayar. Gagal bayar merupakan kondisi di mana seorang penerima pinjaman dalam perjanjian utang piutang tidak dapat melaksanakan kewajiban yang ada dalam perjanjian utang piutang yang telah dibuat. Gagal bayar dikenal dengan sebutan non-performing loan (NPL), dalam penyelenggaraan Peer to Peer Lending, gagal bayar disebut tingkat wanprestasi 90 yang selanjutnya disingkat TKW90 yang menginformasikan terkait ukuran tingkat wanprestasi atau kelalaian 
Salsabila Yuharnita: Kebijakan Restrukturisasi Pinjaman...

penyelesaian kewajiban di atas 90 hari sejak tanggal jatuh tempo. ${ }^{4}$ Tingkat gagal bayar oleh penerima pinjaman yang meningkat akan berpengaruh terhadap tingkat keberhasilan bayar pada hari ke-90 atau biasa disebut TKB90. Semakin kecil nilai TKW90 maka semakin besar TKB90, tetapi apabila nilai TKW90 besar akan diikuti dengan kecilnya nilai TKB90. Semakin tinggi persentase TKB90 yang tertera menandakan keberhasilan penyelenggaraan pinjam meminjam yang dilakukan oleh penyelenggara.

\section{Kebijakan Restrukturisasi Pinjaman pada Peer to Peer Lending akibat Pandemi Covid-19}

Dalam penyelenggaraan Peer to Peer Lending tentu dimungkinkan adanya risiko-risiko yang dihadapi, salah satunya risiko gagal bayar atau Non-Performing Loan (NPL). Pada dasarnya penyelenggara Peer to Peer Lending tidak memiliki kewenangan untuk memberikan restrukturisasi, namun penyelenggara Peer to Peer Lending dapat memberi fasilitas pengajuan restrukturisasi pinjaman usaha mikro, kecil, dan menengah (UMKM), Sebelum adanya pandemi Covid-19 dimungkinkan adanya restruktrukturisasi pinjaman sesuai dengan ketentuan masing-masing penyelenggara.

Saat ini, belum ada peraturan khusus dari OJK terkait restrukturisasi pinjaman pada Peer to Peer Lending, sehingga kebijakan restrukturisasi diserahkan kepada masing-masing penyelenggara. Asosiasi Fintech Pendanaan Bersama Indonesia (AFPI) menghimbau kepada penyelenggara Peer to Peer Lending secara aktif berpartisipasi untuk membantu dan meringankan pengguna Peer to Peer Lending yang mengalami kerugian atas COVID-19. AFPI menghimbau kepada penyelenggara Peer to Peer Lending untuk memberikan fasilitas pengajuan restrukturisasi pinjaman usaha mikro, kecil, dan menengah (UMKM) yang ditujukan pada pemberi pinjaman. Restrukturisasi pinjaman

\footnotetext{
4 Amartha, 'Apa Itu TKB90 Dan TKW90?' (Amartha, 2019).

5 Drean Muhyil Ihsan, 'Tahukah Anda Arti TKB90 Pada Fintech P2P Lending Atau Pinjol?' (Trenasia, 2020).
} 
dianalisis oleh penyelenggara Peer to Peer Lending dan keputusan diberikan oleh pemberi pinjaman.

Pandemi COVID-19 juga memberikan dampak terhadap penyelenggaraan Peer to Peer Lending, hal ini dibuktikan dengan data statistik bulan November 2020 dari Otoritas Jasa Keuangan. Berdasarkan data Otoritas Jasa Keuangan tersebut, TKB90 pada Desember 2019 menyentuh angka 96,35\% kemudian pada November 2020 mengalami penurunan menjadi 92,82\%, terjadi penurunan sebesar 3,80\% yoy. Hal ini tidak sebanding dengan penyaluran pinjaman dari seluruh penyelenggara Peer to Peer Lending yang mengalami kenaikan sejak Desember 2019, pada November 2020 terjadi kenaikan sebesar 24,82\%. ${ }^{6}$ Kenaikan penyaluran pinjaman merupakan hal yang baik bagi penyelenggaraan Peer to Peer Lending, tetapi perlu diperhatikan terkait penurunan pada TKB90 sejak Desember 2019 sampai November 2020, penurunan TKB90 menandakan kemampuan bayar masyarakat menurun sehingga terjadi keterlambatan pembayaran, salah satu faktor keterlambatan ini karena adanya pandemi COVID-19.

Kebijakan untuk mengatasi gagal bayar pada Peer to Peer Lending bergantung pada masing-masing penyelenggara dikarenakan belum ada aturan yang mengatur terkait kebijakan mengatasi risiko gagal bayar. Bagitu pula setelah Covid-19, penyelenggara kembali memberi fasilitas bagi penerima pinjaman yang terkena dampak COVID-19 melalui mekanisme dan analisis kelayakan pada tiaptiap penyelenggara Peer to Peer Lending dan persetujuan restrukturisasi pinjaman dari pemberi pinjaman.

Beberapa penyelenggara Peer to Peer Lending memberikan fasilitas pengajuan restrukturisasi pinjaman. Fasilitas yang ditawarkan meliputi penerapan Grace Period, perpanjangan tenor, Payment Holiday, dan yang terakhir dilakukannya restrukturisasi. Penjelaskan terkait skema tersebut yaitu: ${ }^{7}$

\footnotetext{
${ }^{6}$ Otoritas Jasa Keuangan (n 3).

7 Walter P, 'Pinjaman Dengan Performa Buruk Dan Gagal Bayar, Perlukah Khawatir?' (Koinworks, 2020).
} 
1. Grace Period

Merupakan masa tenggang yang memungkinkan penerima pinjaman untuk membayar sebagian pokok utang dengan bunga pinjaman atau hanya bunga pinjaman hingga jangka waktu grace period berakhir yang dalam hal ini adalah 3-6 bulan. Setelah masa grace period berakhir, penerima pinjaman akan membayar pokok dan bunga kembali setiap bulan hingga tenor pinjaman berakhir.

2. Perpanjangan tenor

Perpanjangan tenor memberikan keringanan kepada penerima pinjaman untuk tetap membayar pokok dan bunga utang, tetapi jangka waktu pembayaran diperpanjang.

3. Payment Holiday

Merupakan keringanan untuk tidak membayar sampai dengan maksimal 3 (tiga) bulan, setelah batas waktu tersebut, pembayaran dilakukan kembali hingga selesai.

4. Restruktur

Merupakan keringanan yang memperkecil jumlah angsuran atau memperpanjang lama angsuran selama maksimal 24 bulan untuk industri yang terkena dampak COVID-19 dan proyek-proyek yang mengalami penundaan.

\section{Upaya yang tepat dalam mengatasi gagal bayar Peer to Peer Lending saat pandemi}

\section{Covid-19}

Upaya yang ditawarkan oleh penyelenggara Peer to Peer Lending merujuk pada upaya restrukturisasi kredit perbankan yang diatur dalam POJK Nomor 11/POJK.03/2020 tentang Stimulus Perokonomian Nasional Sebagai Kebijakan Countercyclical Dampak Penyebaran Coronavirus Disease 2019. Restrukturisasi kredit dilakukan dengan beberapa cara, antara lain:

a) Penurunan suku bunga kredit;

b) Perpanjangan jangka waktu kredit;

c) Pengurangan tunggakan pokok kredit;

d) Pengurangan tunggakan bunga kredit; 
e) Penambahan fasilitas kredit;

f) Konversi kredit menjadi Penyertaan Modal Sementara.

Merujuk pada cara-cara restrukturisasi kredit perbankan tersebut, penyelenggara Peer to Peer Lending kemudian menerapkan beberapa cara yang dapat dilakukan pada Peer to Peer Lending mengingat karakteristik perjanjian kredit perbankan dan perjanjian pinjam meminjam pada Peer to Peer Lending berbeda, sehingga tidak semua cara restrukturisasi kredit perbankan dapat diterapkan pada penyelenggaraan Peer to Peer Lending.

Dari 6 cara restrukturisasi yang tercantum dalam POJK Nomor 11/ POJK.03/2020 tentang Stimulus Perokonomian Nasional Sebagai Kebijakan Countercyclical Dampak Penyebaran Coronavirus Disease 2019 ada cara yang tidak dapat diterapkan pada penyelenggaraan Peer to Peer Lending yaitu penambahan fasilitas kredit serta konversi kredit menjadi penyertaan modal sementara. Kedua cara tersebut tidak dapat dilakukan dalam Peer to Peer Lending karena tidak sesuai dengan karakteristik Peer to Peer Lending

Melihat beberapa cara yang dapat diterapkan dalam restrukturisasi pinjaman pada Peer to Peer Lending berdasar POJK Nomor 11/POJK.03/2020 dan yang diterapkan oleh penyelenggara Peer to Peer Lending sebelum pandemi Covid-19, terdapat cara yang paling sering digunakan oleh penyelenggara Peer to Peer Lending, yaitu perpanjangan waktu pinjaman atau perpanjangan tenor dan Grace Period. Kedua cara ini merupakan cara yang paling tepat untuk diterapkan dalam menyelesaikan perkara gagal bayar dalam Peer to Peer Lending. Untuk mendapatkan fasilitas restrukturisasi pinjaman, penerima pinjaman harus mengajukan terlebih dahulu yang kemudian keputusannya akan diberikan oleh pemberi pinjaman.

\section{Penyelesaian sengketa dalam Peer to Peer Lending}

Dalam penyelenggaraan Peer to Peer Lending dimungkinkan terjadi sengketa antara pengguna yaitu pemberi pinjaman dengan penerima pinjaman ataupun sengketa antara pengguna dengan penyelenggara. Sengketa ini terjadi karena 
Salsabila Yuharnita: Kebijakan Restrukturisasi Pinjaman...

terjadi wanprestasi dalam perjanjian yang dilakukan. Perlindungan hukum kepada konsumen dan masyarakat diperlukan saat terjadi sengketa, untuk itu Otoritas Jasa Keuangan menerbitkan Peraturan Otoritas Jasa Keuangan Nomor 18/POJK.07 Tahun 2018 tentang Layanan Pengaduan Konsumen di Sektor Jasa Keuangan. POJK Nomor 18/POJK.07/2018 yang memberikan sebuah layanan kepada konsumen untuk menampung pengaduan oleh pelaku usaha jasa keuangan (PUJK) dan mengusahakan penyelesaian dari pengaduan tersebut.

Jika konsumen ataupun tim perwakilan konsumen menolak tanggapan pengaduan dari PUJK, selanjutnya PUJK memiliki kewajiban untuk memberi informasi kepada konsumen atau tim perwakilan konsumen terkait upaya penyelesaian sengketa yang dapat dilakukan secara litigasi atau non-litigasi. Klausul terkait pemilihan penyelesaian sengketa yang akan dilakukan dituangkan dalam perjanjian antara PUJK dengan Konsumen. ${ }^{8}$ Penyelesaian sengketa yang dilakukan dengan jalur non-litigasi melalui Lembaga Alternatif Penyelesaian Sengketa (LAPS) berdasarkan Pasal 25 POJK18/ POJK.07/2018. Apabila prosedur non-litigasi tidak tercapai kesepakatan damai, maka upaya yang dapat dilakukan adalah melalui jalur litigasi dengan mengajukan gugatan perdata. Jalur litigasi yang tepat untuk sengketa Peer to Peer Lending yaitu dengan gugatan sederhana, hal ini sesuai dengan kewajiban dari penyelenggara Peer to Peer Lending yaitu penyelesaian sengketa dilakukan secara sederhana, cepat dan biaya terjangkau.

\section{Daftar Bacaan}

\section{Jurnal}

Trisadini Prasastinah Usanti, Fiska Silvia APS, 'Dispute Settlement Method for Lending in Supply Chain Financial Technology in Indonesia' (2020) 9 International Journal of Supply Chain Management http://www.ojs. excelingtech.co.uk/index.php/IJSCM/article/view/ 4883.

8 Anindya Prastiwi Setiawati Trisadini Prasastinah Usanti, Fiska Silvia, 'Dispute Settlement Method for Lending in Supply Chain Financial Technology in Indonesia' (2020) 9 International Journal of Supply Chain Management <http://www.ojs.excelingtech.co.uk/index.php/IJSCM/ article/view/4883>. 
Trisadini Prasastinah Usanti et al, 'The Legal Principle of Collateral in Fintech Lending' (2019) 3 Hang Tuah Law Journal http://law-journal.hangtuah. ac.id/index.php/htlj/article/view/137.

\section{Laman}

Amartha, 'Apa Itu TKB90 dan TKW90?', (Amartha, 2019) < https:/ / blog.amartha. com/apa-itu-tkb90-dan-tkw90/>, dikunjungi pada 26 November 2020.

Drean Muhyil Ihsan, 'Tahukah Anda Arti TKB90 Pada Fintech P2P Lending atau Pinjol?', (Trenasia, 2020) <https://www.trenasia.com/tahukah-andaarti-tkb90-pada-fintech-p2p-lending-atau-pinjol/>, dikunjungi pada 26 November 2020.

Otoritas Jasa Keuangan, 'Perusahaan Fintech Lending Berizin Dan Terdaftar Di OJK', (Otoritas Jasa Keuangan, 2020) <https://www.ojk.go.id/id/ kanal/iknb/data-dan-statistik/fintech/Documents/Statistik\%20FL\%20 November.pdf $>$, dikunjungi pada 6 Januari 2020.

R Quiserto, 'Cara Restrukturisasi Pinjol Pinjaman Online Fintech P2P Covid-19 2020', (Duwitmu, 2020) <https://duwitmu.com/pinjaman-online/ restrukturisasi-pinjaman-online-fintech-p2p/amp/>, 24 Agustus 2020, h.1, dikunjungi pada 28 Agustus 2020.

Walter P, "Pinjaman Dengan Performa Buruk dan Gagal Bayar, Perlukah Khawatir?", (Koinworks, 2020) <https://koinworks.com/blog/kerugiangagal-bayar/>, dikunjungi pada 31 Oktober 2020.

\section{Perundang-undangan}

Burgelijk Wetboek voor Indonesie / Kitab Undang-Undang Hukum Perdata (Staatsblad Tahun 1847 Nomor 23).

Keputusan Presiden No. 12 Tahun 2020 tentang Penetapan Bencana Nonalam Penyebaran Corona Virus Disease 2019 (COVID-19) Sebagai Bencana Nasional

Peraturan Bank Indonesia (PBI) Nomor 19/12/ PBI/2017 Tentang Penyelenggaraan Teknologi Finansial (Lembaran Negara Republik Indonesia Tahun 2017 Nomor 245).

Peraturan Otoritas Jasa Keuangan Nomor 77/POJK.01/2016 tentang Layanan Pinjam Meminjam Uang Berbasis Teknologi Informasi (Lembaran Negara Republik Indonesia Tahun 2016 Nomor 324).

Peraturan Otoritas Jasa Keuangan Nomor 18/POJK.07 Tahun 2018 tentang Layanan Pengaduan Konsumen di Sektor Jasa Keuangan (Lembaran Negara 
Republik Indonesia Tahun 2018 Nomor 150).

Peraturan Otoritas Jasa Keuangan No. 11/POJK.03/2020 tentang Stimulus Perekonomian Nasional Sebagai Kebijakan Countercyclical Dampak Penyebaran Corona Virus Disease 2019 (Lembaran Negara Republik Indonesia Tahun 2020 Nomor 76).

How to cite: Salsabila Yuharnita, 'Kebijakan Restrukturisasi Pinjaman Pada Peer To Peer Lending' (2021) Vol. 4 No. 1 Media Iuris. 